\title{
An Empirical Analysis of Pension Funds Assets Influencing Infrastructure Financing in Nigeria
}

\author{
Roseline Oluwatoyin Oluitan ${ }^{1}$ \\ Lagos State University, Ojo, Lagos State, Nigeria \\ \& \\ Ojuolape Amoke Falode ${ }^{2}$ \\ Lagos State University, Ojo, Lagos State, Nigeria
}

\begin{abstract}
This paper examined Pension Fund Assets (PFA)and Infrastructural Financing (INFF) in Nigeria. The Generalized Methods of Moment was used to analyze secondary data of Pension Fund Administrators. The findings show that PFA has a positive and significant effect on INFF. GDP and PFA ratio was found significant in INFF positively and Capital expenditure and PFA ratio had a positive and significant effect on INFF. Inflation however has a negative and significant effect on INFF. The paper recommends PFA as an alternative source of INFF provided measures are taken to prevent its abuse.
\end{abstract}

Keywords: Pension Fund Assets, Infrastructural Financing, Nigeria.

\section{Introduction}

The declining trend in the growth rate of the Nigerian economy can be been attributed to the poor state of infrastructure development. Recently, it was discovered that one of the major features of Nigeria's dwindling growth performance has been a massive decline in physical infrastructure development (Ogunlana et al, 2016). This is anchored on the slow movement of goods and services due to inaccessible and most times unavailability of road infrastructure in the country.

The increasing debt profile has led to a search for affordable funding alternatives; preferably 'locally denominated debts' for use in funding infrastructure. The Banking and Financing structure in Nigeria currently is short term focused; regulatory pressures and the recent economic slumps due to varying factors have seen banks investing less in infrastructure. The long term nature of Pension Fund Management, however, makes it seem to be a feasible alternative source for infrastructure funding.

The recent global financial and economic crises have worsened the situation, further reducing the scope for public investment in infrastructure within governments' budgets in several countries, including Nigeria. Although multilateral institutions have provided some level of support for infrastructural financing, the support, however, is inadequate to address the country's huge infrastructural financing gap. This study seeks to examine the possibility of using pension fund assets in financing infrastructure to foster economic growth in Nigeria. In doing this, there is a major financing question to answer:

\subsection{Research Question}

1 To what extent will Pension Fund Assets influence Infrastructure Financing in Nigeria?

\subsection{Research Objectives}

The broad objective of the study is:

1 To examine the possibility of pension fund administrators' investment in infrastructure to finance and foster economic growth in Nigeria while the specific objective is;

2 To examine the influence of Pension Fund Assets on Infrastructure Financing in Nigeria. 


\subsection{Research Hypotheses}

Given the above, the following hypothesis is formulated for testing in this study. However, the hypothesis formulated for this study is captured in its null form;

\subsubsection{Hypothesis One}

$\mathrm{H}_{0}$ : Pension Fund Assets do not have a significant influence on Infrastructure Financing in Nigeria.

\subsection{Significance of the Study}

A study of this nature is justified on the continuous increase in the debt profile of the country coupled with the obvious infrastructure deficit we are faced with. This Gap in infrastructure finance has led to the necessity to seek for other alternatives to funding. It has become a major concern to Nigerian government about the ways and means to finance infrastructure in the country as no economy can achieve any significant growth in the absence of good basic social and economic infrastructure; Nigeria is fraught with bad roads, epileptic power supply, poor healthcare, and educational facilities. This along with the current debt burden borne by the federal government (both local and foreign-denominated debt) has necessitated a need to seek innovating alternate "infrastructure financing" options.

The foregoing suggests a need for a more robust study on how Pension Fund Administrators' investment in infrastructure would finance Infrastructure Development in Nigeria.

\section{Literature Review}

This aspect of this paper comprises the theoretical, conceptual and empirical framework, which are discussed separately below.

\subsection{Conceptual Framework}

Infrastructure is viewed as a purely public good, built and maintained with public funds. In recent years, however, the increasing constraints on public finances, associated with growing demands for social expenditures, have posed great challenges in the maintenance of existing infrastructure and the construction of new facilities (Tule, Okafor, Obioma, Okorie, Oduyemi, Muhammad and Olaoye, 2015). It is the fundamental facilities and systems serving a country, city, or other areas, including the services and facilities necessary for its economy to function. It has also been defined as "the physical components of interrelated systems providing commodities and services essential to enable, sustain, or enhance societal living conditions (Jeffrey, 2009).

There are two main perspectives to viewing infrastructure; hard or soft. Hard infrastructure refers to the physical networks necessary for the functioning of the modern industry. This includes roads, bridges, railways, etc. while Soft infrastructure refers to all the institutions that maintain the economic, health, social, and cultural standards of a country. This includes educational programs, official statistics, parks, and recreational facilities, law enforcement agencies, and emergency services(The New Palgrave Dictionary of Economics, (2008)). The above construct forms the concept of 'infrastructure' of the study.

Infrastructure development in Nigeria has conventionally been financed by the Federal Government, Loans from Developmental Finance Institutions and Grants from Foreign Aid Organizations. However, Public Deficits increased public debt to GDP ratios and, at times, the inability of the public sector to deliver efficient investment spending, have in many economies led to a reduction in the level of public funds allocated to infrastructure (OECD, 2015).

Pensions are institutional funds into which a sum of money is added during an employee's employment years, and from which payments are drawn to support the person's retirement from work in the form of periodic payments (Economist, 2008). It is managed and administered by Pension Fund Administrators to meet the social welfare needs of the population thus insuring against income loss at old age and the life cycle risks of the society. The National Pension Commission (Pencom) is the body that supervises and regulates the Nigerian Pension Industry. The Pension Reform Act, 2014 is the Legislation that guides the administration of retirement benefits in the nation. The Act lays down the scope of investments that Pension Fund Assets can be invested in. 


\subsubsection{Pension Fund Assets as an Investment in Infrastructure}

Over the years, pension funds have increasingly been classified into a new asset in a bid to redefine its purpose, yield, and usefulness both to individuals and the government. Infrastructure isone type of investment that is frequently discussed, given its potential to match long-term pension assetsand provide diversification. In the past, pension funds exposure to infrastructure has been done through listed companies (such as utilities), orreal estate portfolios. However, some larger funds globally are beginning to invest through private-equity funds, or, occasionally, even directly. In international climes such as Australia, Canada, and Denmark, pension funds may be considered as leaders in this field (Inderst, 2009).

There are however obstacles to such investment intentions especially political risks involved with suchlong-term investments. The experience of pension funds around the world with such assets has notalways been positive. Some issues preventing Pension Fund Assets financing Infrastructure in Nigeria include but are not limited to:

- $\quad$ Lack of projects available that meet Pencom's criteria for pension funds investing in infrastructure.

- $\quad$ The problem of Misappropriation of Pension fund Assets.

- Unstable political environment: a change in leadership may lead to abandoned projects.

- $\quad$ Lack of transparency in bidding processes.

- $\quad$ Lack of will on the part of investors to invest in long term projects.

While some experts argue that pension funds are too risk-averse to invest in risky, decades-long infrastructure projects, others contend that with the right governance, regulation, and instruments to assess and manage the risks associated with long-term investment in infrastructure, pension funds could take on a greater role in transforming the continent's infrastructure landscape (Amadou, 2017).

\subsection{Theoretical Review}

The 'Theory of Capital Accumulation 'is the theoretical underpinning of the study; it highlights the importance of harnessing pension funds for long term investment in infrastructure.

\subsubsection{Theory of Capital Accumulation by Karl Marx}

In Karl Marx's economic theory, Capital Accumulation is the operation whereby profits are reinvested into the economy, increasing the total quantity of capital. The capital was understood by Marx to be expanding value, that is, in other terms, as a sum of capital, usually expressed in money that is transformed through human labor into a larger value and extracted as profits. Here, Capital is defined essentially as economic or commercial asset value that is derived, in this case from the infrastructural development.

It was discovered that one of the strategies of development necessary for any ascent is the mobilization of domestic savings to generate sufficient investment to accelerate economic growth. This is the path of infrastructural funding through Pension Fund Assets as a solution to Infrastructural Financing Deficit in Nigeria.

This assertion was supported by the Harrod-Domar growth model which stated that in every economy, the savings ratio (s) and the capital coefficient (k) are regarded as critical factors for capital accumulation and growth assuming that all savings are used to finance fixed investment. The rate of growth ofthe real stock of fixed capital $(\mathrm{K})$ is:

$\frac{\Delta K}{K}=\frac{\Delta K}{\frac{Y}{Y}}=\frac{S}{K}$

where $\mathrm{Y}$ is the Real National Income. If the Capital-Output Ratio or Capital Coefficient $(\mathrm{k}=\mathrm{K} / \mathrm{Y})$ is constant, the rate of growth of $\mathrm{Y}$ is equal to the rate of growth of $\mathrm{K}$. This is determined by (the ratio of Net Fixed Investment or Saving to $\mathrm{Y}$ and $\mathrm{k}$. Therefore, Pension Fund as a source for financing such fixed investments as opined by the Harrod-Domar growth model, is expedient for sustainable development, particularly in the context of financing infrastructure projects.

\subsection{Empirical Review}

Several studies have been undertaken both internationally and locally to identify the relationship that exists between Infrastructure in Nigeria and Pensions as a means to finance it. Some researchers posited that such an alternative source of funding could provide long term financing for infrastructural development (Ogunlana et al (2016). However, several other scholars have examined the importance of pension funds to infrastructural 58 
development. Tule, et al (2015) studied 'Leveraging Pension Funds for Financing Infrastructural Development in Nigeria'; they found that Pension Funds are seen as an additional source of much-needed capital to fund Nigeria infrastructure projects. They also found that it provides a means for individuals to accumulate savings over their working life to finance their consumption needs in retirement, either through a lump sum or by the provision of annuity, while also supplying funds to end-users such as corporations or governments for investment.

$\mathrm{Hu}$ (2012) studied the impact of Asian pension funds, in particular, the key transmission mechanisms from pension reform to financial development. With the aid of the panel error correction model, a statistical relationship between pension asset growth and development of financial and capital markets was established. This was corroborated by Catalan et al. (2000) in their investigation of the relationship between capital markets and contractual savings. The study found that contractual savings institutions, like pension funds, granger-cause capital market development. The study used data on capital market capitalization and value traded from 26 countries, six of which were developing economies.

Gunu et al (2012) studied the effect of the introduction of the Contributory Pension Scheme (CPS) on savings mobilization, capital market development and economic growth stimulation in Nigeria. Using secondary data that were analyzed using descriptive statistics, charts, and percentages, the study noted that pension funds investment as a percentage of the total market capitalization rose consistently from 2.36 percent in 2007 to 4.53 percent at 2010. The paper, therefore, inferred that through the capital market, the CPS had contributed to the general economic development in Nigeria. Della-Croce et al (2011) examined the latest ideas in the world aimed at leveraging pension funds in financing green growth-related projects. The paper itemized various financing options and the role of government and pension fund regulatory and supervisory authorities in utilizing pension funds for economic growth. Major recommendations made by the authors include the need to ensure enabling the business environment, creation of a more liquid market to support the commitment of funds in enhancing green infrastructure and removal of impediments to investment.

Angeliki (2008) studied the effect of pension reforms on macroeconomic performance. Wide-Ranging research on the impact of pension reforms on output, capital stock, and consumption, as well as the underlying factors leading to cross country heterogeneity, was presented. In conclusion, the Author asserted that pension reform brought an improvement in macroeconomic performance. However, it provided evidence that the success recorded was more visible in countries with lower public debt, age dependency ratio, developed financial markets and a higher rate of privatizations.

Beeferman (2008) explained that investing in infrastructure was a potential avenue for a pension fund to reap a higher and consistent yield soon when the fund matured. However, he noted that as lucrative as infrastructure investment might appear, it does not provide a distinct asset class and that fact explains the complexities of investing pension funds in such areas as infrastructure.

\section{Analytical Method and Sources of Data}

Data used for the regression analysis are secondary data collected from the Pension Fund Administrators, Central Bank of Nigeria (CBN), and the National Bureau of Statistics Data Base. The data were collected between 2009 and 2018.

\subsection{Model Specification}

In light of the objectives and hypotheses raised in the introductory section, a multiple regression model is specified. The model specification follows the Generalized Method of Moments (GMM) regression with dependent and independent variables. This estimator is used to avoid the problem of endogeneity in the model. It is a general estimation principle derived from 'moment conditions'; this is due to the ability of GMM to estimate the model with minimum error. The GMM method requires that a certain number of moment conditions are specified for the model. It then minimizes a certain norm of the sample averages of the moment conditions. The GMM method combines observed economic data with the information in population moment conditions to produce estimates of the unknown parameters of the economic model. 


\subsubsection{Infrastructural Financing Model}

The models are therefore specified as thus:

$\mathrm{INFF}=\mathrm{f}(\mathrm{PFA}, \mathrm{EXPF}, \mathrm{GPFS}$ and INF $)$

In $Y_{\text {it }}=\quad \alpha \operatorname{In} Y_{\text {it }-1}+\beta X_{\text {iti }}^{\prime}+\varepsilon_{\text {it }}$

Transforming the functional form model into a linear econometrics model with the introduction of parameters suggests the introduction of the intercept term which connotes constant variable and error term that subsumes other variables that might be crucial to infrastructural financing not shown in the model. The model is specified thus;

$\operatorname{InINFF}_{\text {it }}=\alpha \operatorname{InINFF}_{\text {it }-1}+Y^{z^{\prime}}+\beta_{1} \operatorname{InEXPF}_{t}+\beta_{2} \operatorname{InPFA}_{t}-\beta_{3} \operatorname{INF}_{t}+\beta_{2} \operatorname{InGPFA}_{t}+\varepsilon_{\text {it }}$

Where:

LINFF $=$ Log of Infrastructural Financing measured by Government Capital Expenditure (GCE)

$\mathrm{EXPF}=$ Pension Fund Assets and Capital Expenditure ratio

LPFA $=$ Log of Pension Fund Assets

GPFA $=$ Pension Fund Assets and GDP ratio

LINF $=$ Log of Rate of Inflation within the period under study

$Z^{\prime}=$ Control Variables

$\beta_{1-} \beta_{2}$ represents the slope coefficientsthat measure the changes in the independent variables to the dependent variablewhile $\mu_{\mathrm{t}}=$ Error Term

\section{Empirical Results}

\subsection{Descriptive Analysis}

Table I Showing Result of Descriptive Analysis

\begin{tabular}{r|rrrr|r}
\hline & \multicolumn{1}{|c}{ LINFF } & \multicolumn{1}{l|}{ LPFA } & EXPF & \multicolumn{1}{c|}{ LINF } & \multicolumn{1}{c}{ GPFA } \\
\hline Mean & 8.951509 & 9.385282 & 0.715528 & 1.100274 & 0.00927 \\
Median & 8.9516 & 9.368589 & 0.425373 & 1.075532 & 0.004579 \\
Maximum & 9.061754 & 10.69517 & 4.317603 & 1.355068 & 0.101871 \\
Minimum & 8.802637 & 8.401401 & 0.015424 & 0.90309 & 0.000612 \\
Std. Dev. & 0.070821 & 0.503605 & 0.893792 & 0.152653 & 0.014052 \\
\hline Skewness & -0.38222 & 0.217431 & 2.039313 & 0.286045 & 3.954897 \\
Kurtosis & 2.960998 & 2.84608 & 6.621738 & 1.785679 & 22.53748 \\
Jarque-Bera & 2.441213 & 0.886653 & 123.9674 & 7.507753 & 1851.158 \\
Probability & 0.295051 & 0.641898 & 0.0000 & 0.023427 & 0.0000 \\
Sum & 895.1509 & 938.5282 & 71.55283 & 110.0274 & 0.92695 \\
Sum Sq. Dev. & 0.496544 & 25.10818 & 79.08755 & 2.30699 & 0.019547 \\
\hline Observations & 100 & 100 & 100 & 100 & 100 \\
\hline
\end{tabular}

Source: Authors Computation (2019) using Eviews 10.0

Table I, shows the descriptive analysis of Infrastructural Financing (LINFF) and Pension fund in Nigeria between 2009 and 2018 with components as Pension Fund Assets (LPFA), Pension Fund and Expenditure ratio (EXPF), Inflation (LINF) and PFA, Gross Domestic Productratio (GPFA).The average LINFF between 2009 and 2018 is 8.95 billion with the highest value of 9.06 billion, the lowest value of 8.08 billion and a standard deviation of 0.007 billion with a median of 8.95. Meanwhile, the Jarque-Bera value of 2.44 with a probability value of 0.29 suggests that the LINFF is normally distributed because the p-value is greater than a 5\% level of significance. As regards LPFA, it has an average value of 9.38 with the highest and lowest values of 10.68 and8.40 million. LPFA has a median value of 9.36 with a standard deviation of 0.50 suggesting that the deviation from the sample mean of LPFA is 0.50 . Meanwhile, the Jarque-Bera value of 0.88 with a probability value of 0.64 suggests a normally distributed variable because the p-value is less than a 5\% level of significance. From the value of the kurtosis, it suggests that LPFA has values less than the sample mean of 9.38 . 
Furthermore, the average value of EXPF is 0.715 million with a median value of 0.45 . EXPF has the highest and lowest values of 4.31 million and 0.015 million. The deviation from the sample of EXPF is 0.89 . Meanwhile, the Jarque-Bera value of 123.9 with a probability value of 0.000 suggests that the EXPF is not normally distributed because the p-value is less than a 5\% level of significance. From the value of the kurtosis (6.621), it suggests that EXPF has values higher than the sample mean of 9.24.

The average value of LINF is 1.10 with a median value of 1.07 , Highest and lowest values of $1.35 \%$ and 0.905 . The deviation from the sample of LINF is 0.15 . LINF has a skewness of 0.28 suggesting a long right tail. However, the kurtosis of 1.78 also suggests that LINF is Mesokurtic because the value is less than $3(1,78>3)$. Meanwhile, the Jarque-Bera value of 7.50 with a probability value of 0.02 suggests that LINF is not normally distributed because the p-value is less than a 5\% level of significance. From the value of the kurtosis, it suggests that LINF has values that less than the sample mean of 1.10 .

GPFA has an average value of 0.009 billion Naira with a median value of 0.0045 billion naira and the highest and lowest of the value of 0.101 billion naira and0.0006 billion naira. The deviation from the sample of GPFA is 0.014. Meanwhile, the Jarque-Bera value of 1851.158 with a probability value of 0.000 suggests that GPFA is not normally distributed because the p-value is less than a $5 \%$ level of significance.

\subsection{Stationarity Test}

To guide against an erroneous or misleading result, the study first tested the stationarity of the data. This is important because most panel data exhibit non-stationary behavior in their level form. The Levin, Lin \& Chu t*and Im, Pesaran and Shin W-stat Panel Unit Roottests were adopted.

Table II Levin, Lin \& Chu t*and Im, Pesaran and Shin W-stat PanelUnit Root Test Result

\begin{tabular}{c|ccccc|c}
\hline Variables & $\begin{array}{c}\text { Levin, Lin \& } \\
\text { Chu t* }\end{array}$ & $\begin{array}{c}\text { Prob. } \\
\text { Values }\end{array}$ & Decision & $\begin{array}{c}\text { Im, Pesaran and } \\
\text { Shin w-stat }\end{array}$ & $\begin{array}{c}\text { Prob. } \\
\text { Values }\end{array}$ & Decision \\
\hline LINFF & -7.98699 & 0.0000 & $\mathrm{I}(0$ & -5.11925 & 0.0000 & $\mathrm{I}(0)$ \\
LPFA & -11.2544 & 0.0000 & $\mathrm{I}(0)$ & -5.95889 & 0.0000 & $\mathrm{I}(0)$ \\
EXPF & -4.49862 & 0.0000 & $\mathrm{I}(0)$ & -4.13737 & 0.0014 & $\mathrm{I}(0)$ \\
LINF & -6.02602 & 0.0035 & $\mathrm{I}(0)$ & -1.88427 & 0.0028 & $\mathrm{I}(0)$ \\
\hline GPFA & -24.4813 & 0.0001 & $\mathrm{I}(0)$ & -4.68040 & 0.0028 & $\mathrm{I}(0)$ \\
\hline
\end{tabular}

Source: Researchers Computation (Eviews10.1)

The stationarity test reported in table II shows Levin, Lin \& Chu t and Im, Pesaran and Shin W-statistics shows that Infrastructure Financing(INFF) and Pension funds and its components of LPFA, EXPF, LINF, and GPFAwere found stationary at levels. This indicates that the model is stationary at level $I(0)$. Since the data were found stationary, the data were estimated with the 'Generalized method of Moments'(GMM) to examine the relationship between the components of Pension Funds (EXPF, PFA, INF, and GPFA) and infrastructure financing (INFF). 


\section{Table III: Effect of Pension Fund on Infrastructure Financing in Nigeria}

Dependent Variable: LINFF

Method: Panel GMM EGLS (Period SUR)

Date: 10/21/19 Time: 22:01

Sample: 20092018

Periods included: 8

Cross-sections included: 10

Total panel (unbalanced) observations: 80

White period-instrument weighting matrix

Linear estimation after one-step weighting matrix

Instrument specification: C LITR AGE UNEMPR M2 MPR GENDER

Constant added to instrument list

\begin{tabular}{crlrr}
\hline \hline \multicolumn{1}{c}{ Variable } & Coefficient & Std. Error & t-Statistic & Prob. \\
\hline \hline C & -10.52824 & 0.964597 & -10.91465 & 0.0000 \\
GPFA & 17.80627 & 0.783055 & 22.73949 & 0.0000 \\
EXPF & 1.076689 & 0.049569 & 21.72096 & 0.0000 \\
LINF & -1.285059 & 0.256014 & -5.019488 & 0.0000 \\
LPFA & 0.372374 & 0.018051 & 20.62884 & 0.0000 \\
\hline \hline & \multicolumn{2}{l}{ Weighted Statistics } & \\
\hline \hline R-squared & 0.994422 & Mean dependent var & -21.92801 \\
Adjusted R-squared & 0.994185 & S.D. dependent var & 677.2019 \\
S.E. of regression & 0.981028 & Sum squared resid & 90.46711 \\
Durbin-Watson stat & 2.150611 & J-statistic & 3.894670 \\
Instrument rank & 7 & Prob(J-statistic) & 0.142654
\end{tabular}

Source: Eviews, (2019)

\subsection{Empirical Result and Analysis}

Table III shows the result of the estimated Infrastructural Financing (LINFF) model. The result shows that Pension Fund Assets and GDP ratio(GPFA)have a positive sign which suggests a positive relationship with INFF. This shows that a percent increase in GPFA will lead to a17.8 percent increase in (the availability of fund for) infrastructure financing in Nigeria. The sign of Pension Fund and Government Capital Expenditure Ratio (EXPF) suggests that a percent increase in EXPF will lead to a 1.07 percent increase in infrastructure financing.

The sign of Pension Fund Assets (LPFA) also shows that a percent increase in LPFA will lead to a 0.37 percent increase in LINFF. Lastly, one of the control variables, Inflation (LINF) has a negative sign suggesting that the explanatory variable, inflation has a negative relationship with LINFF within the period under review. This shows that a 1 percent increase in the inflation rate will lead to a 1.28 percent decrease in infrastructure financing in Nigeria.

The validity of the instrument was affirmed by the $\mathbf{J}$ statistic (3.89) showing that the model aptly describes the data. In addition to the above, the coefficients of individual variables show that the explanatory variables are statistically significant while the $\mathrm{R}^{2}$ and adjusted $\mathrm{R}^{2}$ show that the model is fit. The Durbin Watson (D.W) statistics of 2.15 was found substantially very close to the traditional benchmark of 2.0 in the model. This suggests no sign of autocorrelation or serial correlation in the model specification. 


\subsection{Coefficients Diagnostics}

\section{Table IV Result of Wald Test}

Wald Test:

Equation: Untitled

\begin{tabular}{lccc}
\hline \hline Test Statistic & Value & Df & Probability \\
\hline \hline F-statistic & 100345.7 & $(3,94)$ & 0.0000 \\
Chi-square & 301037.1 & 3 & 0.0000 \\
\hline \hline
\end{tabular}

Null Hypothesis: $\mathrm{C}(1)=0, \mathrm{C}(2)=0, \mathrm{C}(4)=3 *(5)$

Null Hypothesis Summary:

\begin{tabular}{lrc}
\hline \hline Normalized Restriction $(=0)$ & Value & Std. Err. \\
\hline \hline $\mathrm{C}(1)$ & -10.52824 & 0.964597 \\
$\mathrm{C}(2)$ & 17.80627 & 0.783055 \\
$-15+\mathrm{C}(4)$ & -16.28506 & 0.256014 \\
\hline \hline
\end{tabular}

Restrictions are linear in coefficients.

Table IVshows the result of the Wald Test. Both the F-distribution (Test Statistic $=100345.7$; P-value_ 0.0000) and the Chi-Square distribution (Test Statistic $=301037.1$ and P-value $=0.0000$ ) indicate that the independent variables (GPFA, EXPF, LPFA and LINF) are jointly significant to influence the dependent variable (LINFF) since their corresponding P-values are less than 5\%. Thus, the null hypothesis is rejected and concludes that the explanatory variables have a significant effect on Infrastructural Financing in Nigeria.

\subsection{Discussion of Findings}

The positive influence of PFA/GEXP ratio(EXPF) shows that an increase in the Pension fund assets to government capital expenditure will have a positive effect of 1.07 percent on the infrastructure financing in Nigeria. The finding supports Channarith and Wade (2010) who found that the growth of pension fundfinancial assets is positively associated with the growth of stock market capitalization, stockvalue traded, and private bond market capitalization.

The positive relationship of LPFA with LINFF as indicated in Table 4.3 shows that a 1 percent increase in LPFA will lead to 0.37 percent increase in LINFF. This is evident in the coefficients of the variable of LPFA $(0.372374$; $\mathrm{p}=0.000$ ) suggesting that it can help finance infrastructure in Nigeria. Inflation was found negative. The negative sign of inflation indicates that the CBN may have carried out monetary policy, encouraging loans and investment noticeable within the last few years and avoiding money hoarding and inefficiencies associated with deflation (Mankiw, 2002).From the foregoing, it is evident that the contributory pension scheme can fund infrastructure.

\section{Conclusion}

This study examines the influence of Pension Fund Assets on Infrastructure Financing in Nigeria. Since the Pension Reform Act 2014 was signed into law to address the challenges faced in Pension Reform Act 2004 implementation processes; Nigeria has experienced significant increases in registered contributors and pension assets. This increased pool of funds could be a potential source for revamping dead infrastructure and improving infrastructural deficit which can pave way for economy development. The Pension Fund Assets are growing rapidly and would increasingly provide a source of investment funds to the domestic financial market. Pension fund investments are expected to increase the availability of long-term funds, enhance competition, induce financial innovation, and improve corporate governance. (Inderst 2009). 
Using Generalized Methods of Moments (GMM), this study finds that Pension Funds' Assets will have a positive and significant impact on Infrastructure Financing measured here by Government Capital Expenditure. This will give the Nigerian economy in a competitive advantage; through investments in new railroads and highways for more effective movement of goods and provision of services amongst others, economic activities would experience accelerated growth.

\subsection{Recommendations}

1. Since the study found that the Pension Fund Assets can be used as an alternative source of financing infrastructure, adequate measures to prevent the abuse of such a scheme should be taken by both PENCOM and other stakeholders;

2. Adequate investment and management of the pool of funds contributed by employees and employersshould be carried out by the Pension Fund Administrators to aid the development of the economy.

3. There should be more emphasis on the management of pension assets in the capital market as well as government bonds, real estate and investment trusts to boost Gross Domestic Product (GDP) of the countryto spur the development of infrastructure.

4. PenCom should ensure effective monitoring, supervision, and enforcement of the provision of the PRA2014, to avoid mismanagement.

5. There should be prompt reconciliation between PFAs, PFCs and PENCOM and statements of accounts should be given to contributors regularly. This will bring transparency and accountability to the system.

6. Professionals should be employed by PFAs to increase competence and professionalism in the Investment of funds, risks, and returns thereon.

\section{References}

Amadou, N.R. (2017) Leveraging African pension funds for financing infrastructure development. Annual Report from Brookings Institution.

Angeliki, T (2008), The Impact of Structural Pension Reforms on the Macroeconomic Performance: An Empirical Analysis,Birkbeck working papers in Economic and Finance, BWPEF 0806

Beeferman, L. W (2008),Pension Fund Investment in Infrastructure: A Resource Paper, Labor and Work-life Program, Harvard Law School, 125 Mt. Auburn St., 3rd Floor, Cambridge, MA 02138

Catalan, M., Impavido, G., \&Musalem, A. R. (2000) Contractual savings or stock market development: which leads? Journal of Applied Social Science Studies, 120(3), 445-87

Channarith, MandWade D.P(2010)The Role of Pension Funds in Capital Market DevelopmentGRIPS Discussion Paper 10-17Oct 2010

Della Croce, R., P-A. Schieb, and B. Stevens (2011).Pension Funds Investment in Infrastructure: A Survey. Geneva: OECD. <http://www.oecd.org/futures/infrastructureto2030/48634596.pdf>27

Economist (2008),Building BRICs of growth. Economist, 7 June 2008, Economic focus, p. 92

Fulmer, Jeffrey (2009). What in the world is infrastructure? PEI Infrastructure Investor (July/August): 30-32.

Gunu, U and Tsado, E (2012), Contributory Pension System as a Tool for Economic Growth in Nigeria, International Journal of Business and Behavioral Sciences Volume 2, Number 8; pp. 6-13, August 2012 Highway Act 197140

$H u, Y$ (2012), Growth of Asian Pension Assets: Implications for Financial and Capital Markets, ADBI Working Paper Series, Number 360, May 2012, Asian Development Bank Institute.

Inderst, G. (2009), "Pension Fund Investment in Infrastructure ", OECD Working Papers on Insurance and Private Pensions, No. 32, OECD publishing, (C) OECD.doi:10.1787/227416754242

India,(2012) Soft Infrastructure - Definition. Archived from the original on 2011-07-23. Retrieved 2019-09-21. Retrieved from

https://web.archive.org/web/20110 723233028/http://www.opendb.net/element/19099.phpon 14/10/2019

Lipshitz, Clive and Walter, Ingo, Bridging Public Pension Funds and Infrastructure Investing (January 20, 2019). Available at SSRN: https://ssrn.com/abstract=3319497 or http://dx.doi.org/10.2139/ssrn.3319497

Mankiw, N. Gregory (2002). "Macroeconomics" (5th ed.). Worth. Measurement of inflation is discussed in Ch. 2, pp. 22-32; Money growth \& Inflation in Ch. 4, pp. 81-107; Keynesian business cycles and inflation in Ch. 9, pp. 238-255. 
National Pension Commission (Pencom), (2019) Regulation on Investment of Pension Funds Assets. www.pencom.gov.ng.

Organization for Economic Co-operation Development, (2015). Infrastructure Financing Instruments and Incentives

Ogunlana O.F., Yaqub J.O and Alhassan, B.T (2016) Infrastructure Finance and Development in NigeriaArabian Journal of Business and Management Review (Nigerian Chapter) Vol. 3, No. 12, 2016

Olanipekun A.O., Aje, I.O. and; Awodele, O.A (2014) Contextualizing Sustainable Infrastructure Development inNigeriaFUTY Journal of the Environment Vol.8 No. 1, June 2014

The New Palgrave Dictionary of Economics, (2008), $2^{\text {nd }}$ Edition. www.dictionaryofeconomics.com

Tule, M.K, Okafor, P.N, Obioma1, E.C, Okorie, G,Oduyemi, A.O, Muhammad A.A., and Olaoye, O.J ( 2015) Leveraging Pension Funds for Financing Infrastructural Development in Nigeria CBN Working Paper Series September 2015

\section{APPENDIX}

\section{Panel Unit Root Test Results}

Panel unit root test: Summary

Series: LINFF

Date: 10/15/19 Time: 07:53

Sample: 20092018

Exogenous variables: Individual effects

Automatic selection of maximum lags

Automatic lag length selection based on SIC: 0

Newey-West automatic bandwidth selection and Bartlett kernel

Balanced observations for each test

\begin{tabular}{lcccc}
\hline \hline & \multicolumn{3}{c}{ Cross- } \\
Method & Statistic & Prob.** & sections & Obs \\
\hline Null: unit root (assumes common unit root process) & & \\
\hline Levin, Lin \& Chu t* & -7.98699 & 0.0000 & 10 & 90 \\
Null: Unit root (assumes individual unit root process) & & \\
\hline Im, Pesaran and Shin W-stat & -5.11925 & 0.0000 & 10 & 90 \\
ADF - Fisher Chi-square & 64.4283 & 0.0000 & 10 & 90 \\
PP - Fisher Chi-square & 64.4283 & 0.0000 & 10 & 90 \\
\hline \hline
\end{tabular}

** Probabilities for Fisher tests are computed using an asymptotic Chi -square distribution. All other tests assume asymptotic normality. 
Panel unit root test: Summary

Series: LGDP

Date: 10/15/19 Time: 07:54

Sample: 20092018

Exogenous variables: Individual effects

Automatic selection of maximum lags

Automatic lag length selection based on SIC: 0

Newey-West automatic bandwidth selection and Bartlett kernel

Balanced observations for each test

\begin{tabular}{|c|c|c|c|c|}
\hline Method & Statistic & Prob.** & $\begin{array}{l}\text { Cross- } \\
\text { sections }\end{array}$ & Obs \\
\hline \multicolumn{5}{|c|}{ Null: unit root (assumes common unit root process) } \\
\hline Levin, Lin \& Chu t* & -7.71043 & 0.0000 & 10 & 90 \\
\hline \multicolumn{5}{|c|}{ Null: Unit root (assumes individual unit root process) } \\
\hline Im, Pesaran and Shin W-stat & -2.98465 & 0.0014 & 10 & 90 \\
\hline ADF - Fisher Chi-square & 41.9386 & 0.0028 & 10 & 90 \\
\hline PP - Fisher Chi-square & 48.3265 & 0.0004 & 10 & 90 \\
\hline
\end{tabular}

** Probabilities for Fisher tests are computed using an asymptotic Chi -square distribution. All other tests assume asymptotic normality.

Panel unit root test: Summary

Series: LPFA

Date: 10/15/19 Time: 07:54

Sample: 20092018

Exogenous variables: Individual effects

Automatic selection of maximum lags

Automatic lag length selection based on SIC: 0 to 1

Newey-West automatic bandwidth selection and Bartlett kernel

\begin{tabular}{|c|c|c|c|c|}
\hline Method & Statistic & Prob.** & $\begin{array}{l}\text { Cross- } \\
\text { sections }\end{array}$ & Obs \\
\hline \multicolumn{5}{|c|}{ Null: Unit root (assumes common unit root process) } \\
\hline Levin, Lin \& Chu t* & -11.2544 & 0.0000 & 10 & 85 \\
\hline \multicolumn{5}{|c|}{ Null: Unit root (assumes individual unit root process) } \\
\hline Im, Pesaran and Shin W-stat & -5.95889 & 0.0000 & 10 & 85 \\
\hline ADF - Fisher Chi-square & 72.5231 & 0.0000 & 10 & 85 \\
\hline PP - Fisher Chi-square & 76.9830 & 0.0000 & 10 & 90 \\
\hline \multicolumn{5}{|c|}{$\begin{array}{l}\text { ** Probabilities for Fisher tests are computed using an asymptotic } \mathrm{Ch} \\
\text {-square distribution. All other tests assume asymptotic normality }\end{array}$} \\
\hline \multicolumn{5}{|l|}{ Panel unit root test: Summary } \\
\hline \multicolumn{5}{|l|}{ Series: LPFL } \\
\hline \multicolumn{5}{|l|}{ Date: 10/15/19 Time: 07:54 } \\
\hline \multicolumn{5}{|c|}{ Sample: 20092018} \\
\hline \multicolumn{5}{|c|}{ Exogenous variables: Individual effects } \\
\hline \multicolumn{5}{|c|}{ Automatic selection of maximum lags } \\
\hline \multicolumn{5}{|c|}{ Automatic lag length selection based on SIC: 0} \\
\hline \multicolumn{5}{|c|}{ Newey-West automatic bandwidth selection and Bartlett kernel } \\
\hline Balanced observations for eac & ch test & & & \\
\hline
\end{tabular}


Cross-

\begin{tabular}{lcccc} 
Method & Statistic & Prob.** & sections & Obs \\
\hline Null: Unit root (assumes common unit root process) & & \\
\hline Levin, Lin \& Chu t* & -7.71043 & 0.0000 & 10 & 90 \\
Null: Unit root (assumes individual unit root process) & \\
\hline Im, Pesaran and Shin W-stat & -2.98465 & 0.0014 & 10 & 90 \\
ADF - Fisher Chi-square & 41.9386 & 0.0028 & 10 & 90 \\
PP - Fisher Chi-square & 48.3265 & 0.0004 & 10 & 90 \\
\hline
\end{tabular}

** Probabilities for Fisher tests are computed using an asymptotic Chi -square distribution. All other tests assume asymptotic normality.

Panel unit root test: Summary

Series: LPFR

Date: 10/15/19 Time: 07:55

Sample: 20092018

Exogenous variables: Individual effects

Automatic selection of maximum lags

Automatic lag length selection based on SIC: 0 to 1

Newey-West automatic bandwidth selection and Bartlett kernel

\begin{tabular}{|c|c|c|c|c|}
\hline Method & Statistic & Prob.** & $\begin{array}{l}\text { Cross- } \\
\text { sections }\end{array}$ & Obs \\
\hline \multicolumn{5}{|c|}{ Null: Unit root (assumes common unit root process) } \\
\hline \multirow{2}{*}{\multicolumn{5}{|c|}{$\begin{array}{lccc}\text { Levin, Lin \& Chu } t^{*} & -9.91350 & 0.0000 & 10 \\
\text { Null: Unit root (assumes individual unit root process) }\end{array}$}} \\
\hline & & & & \\
\hline \multirow{3}{*}{$\begin{array}{l}\mathrm{Im} \text {, Pesaran and Shin W-stat } \\
\text { ADF - Fisher Chi-square } \\
\text { PP - Fisher Chi-square }\end{array}$} & -6.25721 & 0.0000 & 10 & 87 \\
\hline & 78.2308 & 0.0000 & 10 & 87 \\
\hline & 82.8143 & 0.0000 & 10 & 90 \\
\hline \multicolumn{5}{|c|}{$\begin{array}{l}\text { ** Probabilities for Fisher tests are computed using an asymptotic Ch } \\
\text {-square distribution. All other tests assume asymptotic normality }\end{array}$} \\
\hline \multicolumn{5}{|l|}{ Panel unit root test: Summary } \\
\hline \multicolumn{5}{|l|}{ Series: $\mathrm{D}(\mathrm{LINF})$} \\
\hline \multicolumn{5}{|l|}{ Date: $10 / 15 / 19$ Time: 07:57 } \\
\hline \multicolumn{5}{|c|}{ Sample: 20092018} \\
\hline \multicolumn{5}{|c|}{ Exogenous variables: Individual effects } \\
\hline \multicolumn{5}{|c|}{ Automatic selection of maximum lags } \\
\hline \multicolumn{5}{|c|}{ Automatic lag length selection based on SIC: 0} \\
\hline \multicolumn{5}{|c|}{ Newey-West automatic bandwidth selection and Bartlett kernel } \\
\hline Balanced observations for ea & ch test & & & \\
\hline
\end{tabular}

Cross-

Method Statistic Prob.** sections Obs

Null: Unit root (assumes common unit root process)

\begin{tabular}{lllll}
\hline Levin, Lin \& Chu t* & -6.02602 & 0.0000 & 10 & 80
\end{tabular}

Null: Unit root (assumes individual unit root process)

\begin{tabular}{lrrrr}
\hline Im, Pesaran and Shin W-stat & -1.88427 & 0.0298 & 10 & 80 \\
ADF - Fisher Chi-square & 33.0077 & 0.0337 & 10 & 80 \\
PP - Fisher Chi-square & 33.0077 & 0.0337 & 10 & 80
\end{tabular}

** Probabilities for Fisher tests are computed using an asymptotic Chi 
-square distribution. All other tests assume asymptotic normality.

Panel unit root test: Summary

Series: EXPF

Date: 10/18/19 Time: 10:06

Sample: 20092018

Exogenous variables: Individual effects

User-specified lags: 1

Newey-West automatic bandwidth selection and Bartlett kernel

Balanced observations for each test

\begin{tabular}{|c|c|c|c|c|}
\hline Method & Statistic & Prob.** & $\begin{array}{l}\text { Cross- } \\
\text { sections }\end{array}$ & Obs \\
\hline \multicolumn{5}{|c|}{ Null: Unit root (assumes common unit root process) } \\
\hline Levin, Lin \& Chu $t^{*}$ & -4.49862 & 0.0000 & 10 & 80 \\
\hline \multicolumn{5}{|c|}{ Null: Unit root (assumes individual unit root process) } \\
\hline Im, Pesaran and Shin W-stat & -4.13737 & 0.0000 & 10 & 80 \\
\hline ADF - Fisher Chi-square & 57.2023 & 0.0000 & 10 & 80 \\
\hline PP - Fisher Chi-square & 137.326 & 0.0000 & 10 & 90 \\
\hline
\end{tabular}

** Probabilities for Fisher tests are computed using an asymptotic Chi -square distribution. All other tests assume asymptotic normality.

Panel unit root test: Summary

Series: GPFA

Date: 10/18/19 Time: 10:09

Sample: 20092018

Exogenous variables: Individual effects

User-specified lags: 1

Newey-West automatic bandwidth selection and Bartlett kernel

Balanced observations for each test

\begin{tabular}{|c|c|c|c|c|}
\hline Method & Statistic & Prob.** & $\begin{array}{l}\text { Cross- } \\
\text { sections }\end{array}$ & Obs \\
\hline \multicolumn{5}{|c|}{ Null: Unit root (assumes common unit root process) } \\
\hline Levin, Lin \& Chu t* & -24.4813 & 0.0000 & 10 & 80 \\
\hline \multicolumn{5}{|c|}{ Null: Unit root (assumes individual unit root process) } \\
\hline Im, Pesaran and Shin W-stat & -4.68040 & 0.0000 & 10 & 80 \\
\hline ADF - Fisher Chi-square & 30.2755 & 0.0655 & 10 & 80 \\
\hline PP - Fisher Chi-square & 32.9846 & 0.0339 & 10 & 90 \\
\hline
\end{tabular}

** Probabilities for Fisher tests are computed using an asymptotic Chi -square distribution. All other tests assume asymptotic normality. 
TABLE I: PENSION FUND DATA

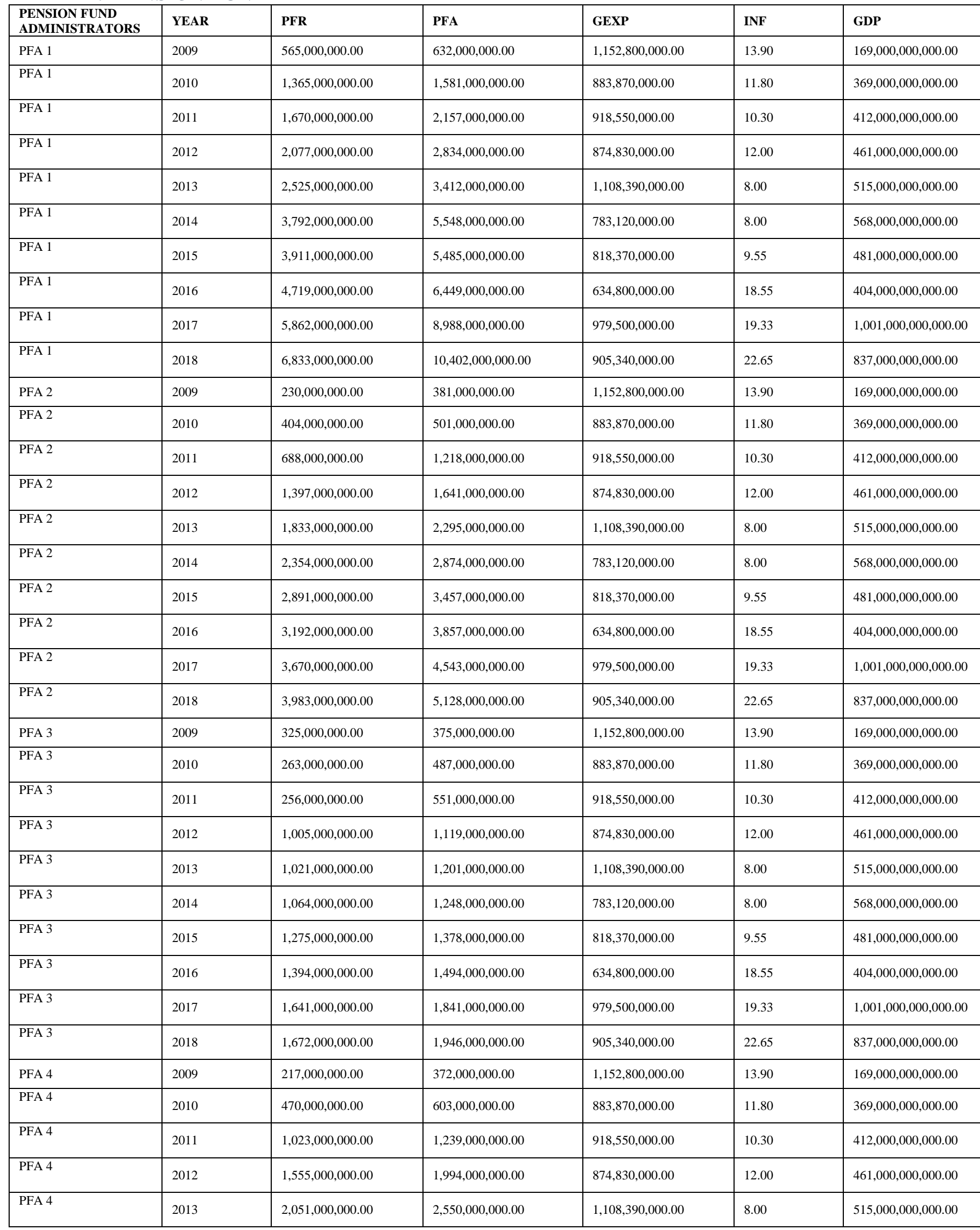




\begin{tabular}{|c|c|c|c|c|c|c|}
\hline PFA 4 & 2014 & $2,734,000,000.00$ & $3,402,000,000.00$ & $783,120,000.00$ & 8.00 & $568,000,000,000.00$ \\
\hline PFA 4 & 2015 & $3,452,000,000.00$ & $4,299,000,000.00$ & $818,370,000.00$ & 9.55 & $481,000,000,000.00$ \\
\hline PFA 4 & 2016 & $4,084,000,000.00$ & $5,125,000,000.00$ & $634,800,000.00$ & 18.55 & $404,000,000,000.00$ \\
\hline PFA 4 & 2017 & $4,994,000,000.00$ & $6,305,000,000.00$ & $979,500,000.00$ & 19.33 & $1,001,000,000,000.00$ \\
\hline PFA 4 & 2018 & $5,490,000,000.00$ & $6,842,000,000.00$ & $905,340,000.00$ & 22.65 & $837,000,000,000.00$ \\
\hline PFA 5 & 2009 & $3,457,000,000.00$ & $5,266,000,000.00$ & $1,152,800,000.00$ & 13.90 & $169,000,000,000.00$ \\
\hline PFA 5 & 2010 & $4,682,000,000.00$ & $7,171,000,000.00$ & $883,870,000.00$ & 11.80 & $369,000,000,000.00$ \\
\hline PFA 5 & 2011 & $6,506,000,000.00$ & $9,554,000,000.00$ & $918,550,000.00$ & 10.30 & $412,000,000,000.00$ \\
\hline PFA 5 & 2012 & $7,860,000,000.00$ & $12,886,000,000.00$ & $874,830,000.00$ & 12.00 & $461,000,000,000.00$ \\
\hline PFA 5 & 2013 & $11,412,000,000.00$ & $18,058,000,000.00$ & $1,108,390,000.00$ & 8.00 & $515,000,000,000.00$ \\
\hline PFA 5 & 2014 & $14,522,000,000.00$ & $22,029,000,000.00$ & $783,120,000.00$ & 8.00 & $568,000,000,000.00$ \\
\hline PFA 5 & 2015 & $18,024,000,000.00$ & $25,836,000,000.00$ & $818,370,000.00$ & 9.55 & $481,000,000,000.00$ \\
\hline PFA 5 & 2016 & $31,696,000,000.00$ & $41,156,000,000.00$ & $634,800,000.00$ & 18.55 & $404,000,000,000.00$ \\
\hline PFA 5 & 2017 & $27,204,000,000.00$ & $38,157,000,000.00$ & $979,500,000.00$ & 19.33 & $1,001,000,000,000.00$ \\
\hline PFA 5 & 2018 & $36,550,000,000.00$ & $49,564,000,000.00$ & $905,340,000.00$ & 22.65 & $837,000,000,000.00$ \\
\hline PFA 6 & 2009 & $3,553,000,000.00$ & $3,744,000,000.00$ & $1,152,800,000.00$ & 13.90 & $169,000,000,000.00$ \\
\hline PFA 6 & 2010 & $5,915,000,000.00$ & $6,456,000,000.00$ & $883,870,000.00$ & 11.80 & $369,000,000,000.00$ \\
\hline PFA 6 & 2011 & $523,000,000.00$ & $564,000,000.00$ & $918,550,000.00$ & 10.30 & $412,000,000,000.00$ \\
\hline PFA 6 & 2012 & $1,065,000,000.00$ & $1,124,000,000.00$ & $874,830,000.00$ & 12.00 & $461,000,000,000.00$ \\
\hline PFA 6 & 2013 & $1,080,000,000.00$ & $1,169,000,000.00$ & $1,108,390,000.00$ & 8.00 & $515,000,000,000.00$ \\
\hline PFA 6 & 2014 & $1,162,000,000.00$ & $1,229,000,000.00$ & $783,120,000.00$ & 8.00 & $568,000,000,000.00$ \\
\hline PFA 6 & 2015 & $1,236,000,000.00$ & $1,295,000,000.00$ & $818,370,000.00$ & 9.55 & $481,000,000,000.00$ \\
\hline PFA 6 & 2016 & $1,403,000,000.00$ & $1,488,000,000.00$ & $634,800,000.00$ & 18.55 & $404,000,000,000.00$ \\
\hline PFA 6 & 2017 & $1,554,000,000.00$ & $1,727,000,000.00$ & $979,500,000.00$ & 19.33 & $1,001,000,000,000.00$ \\
\hline PFA 6 & 2018 & $1,252,000,000.00$ & $1,828,000,000.00$ & $905,340,000.00$ & 22.65 & $837,000,000,000.00$ \\
\hline PFA 7 & 2009 & $235,000,000.00$ & $390,000,000.00$ & $1,152,800,000.00$ & 13.90 & $169,000,000,000.00$ \\
\hline PFA 7 & 2010 & $472,000,000.00$ & $606,000,000.00$ & $883,870,000.00$ & 11.80 & $369,000,000,000.00$ \\
\hline PFA 7 & 2011 & $715,000,000.00$ & $1,166,000,000.00$ & $918,550,000.00$ & 10.30 & $412,000,000,000.00$ \\
\hline PFA 7 & 2012 & $1,393,000,000.00$ & $1,672,000,000.00$ & $874,830,000.00$ & 12.00 & $461,000,000,000.00$ \\
\hline PFA 7 & 2013 & $1,818,000,000.00$ & $2,379,000,000.00$ & $1,108,390,000.00$ & 8.00 & $515,000,000,000.00$ \\
\hline PFA 7 & 2014 & $2,116,000,000.00$ & $2,725,000,000.00$ & $783,120,000.00$ & 8.00 & $568,000,000,000.00$ \\
\hline PFA 7 & 2015 & $2,519,000,000.00$ & $3,229,000,000.00$ & $818,370,000.00$ & 9.55 & $481,000,000,000.00$ \\
\hline PFA 7 & 2016 & $2,737,000,000.00$ & $3,438,000,000.00$ & $634,800,000.00$ & 18.55 & $404,000,000,000.00$ \\
\hline PFA 7 & 2017 & $3,276,000,000.00$ & $4,371,000,000.00$ & $979,500,000.00$ & 19.33 & $1,001,000,000,000.00$ \\
\hline PFA 7 & 2018 & $3,682,000,000.00$ & $4,548,000,000.00$ & $905,340,000.00$ & 22.65 & $837,000,000,000.00$ \\
\hline PFA 8 & 2009 & $212,000,000.00$ & $460,000,000.00$ & $1,152,800,000.00$ & 13.90 & $169,000,000,000.00$ \\
\hline PFA 8 & 2010 & $233,000,000.00$ & $324,000,000.00$ & $883,870,000.00$ & 11.80 & $369,000,000,000.00$ \\
\hline
\end{tabular}




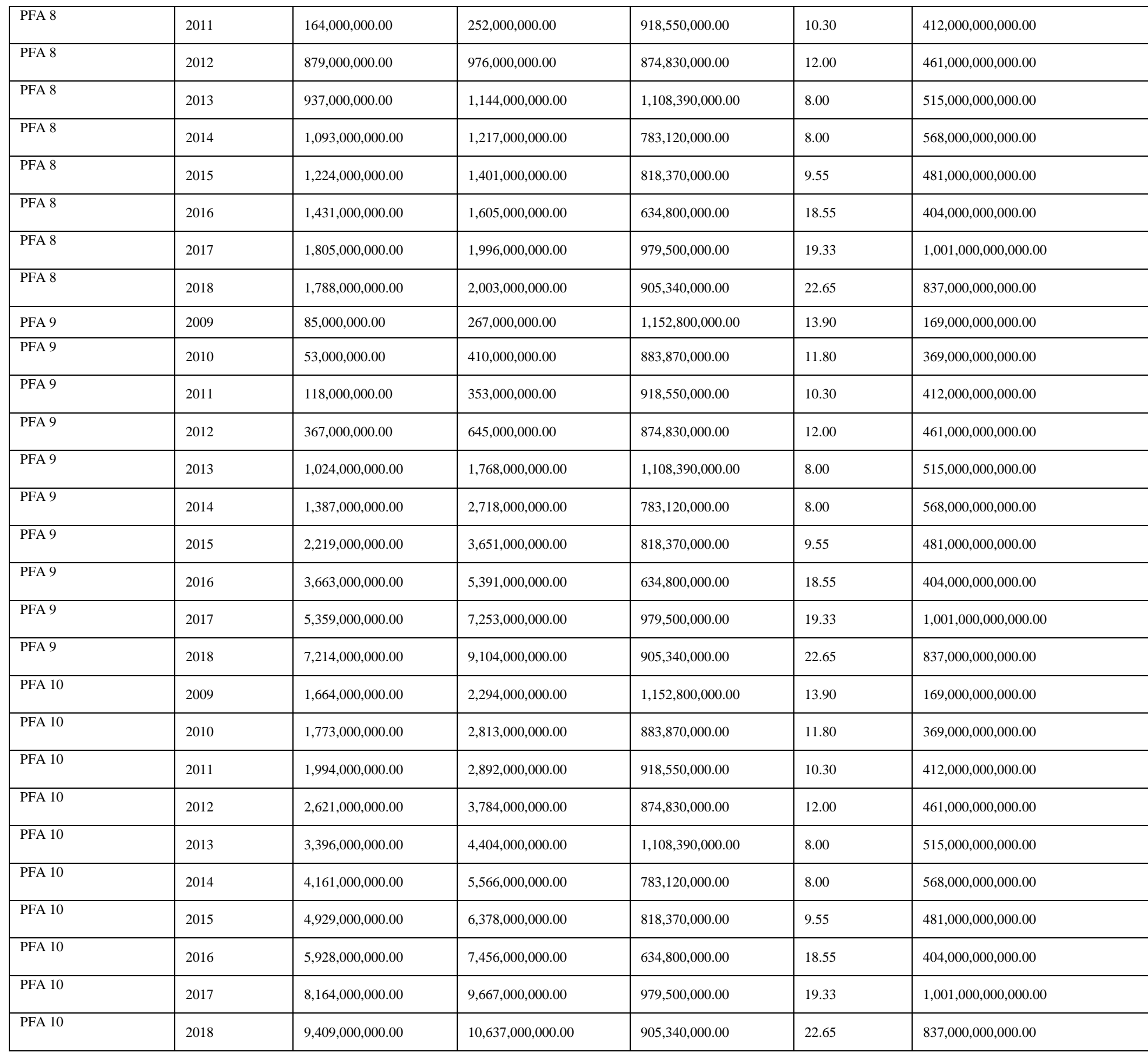

Source: Pension Fund Administrators, Central Bank of Nigeria (CBN), and National Bureau of Statistics Data Base. 